\title{
Presença de literatura húngara traduzida no sistema literário brasileiro
}

\author{
Zsuzsanna Spiry ${ }^{1}$
}

\section{Premissas}

Uma das primeiras questões que surge durante a reflexão sobre a presença no sistema literário brasileiro de literatura húngara traduzida baseia-se na consideração que Antonio Candido ${ }^{2}$ faz quando determina as características de um sistema literário, que, entre outros fatores, está condicionado ao público leitor, mais precisamente à "existência de um conjunto de receptores, formando os diferentes tipos de público, sem os quais a obra não vive" [2007, p. 25]. Portanto, é necessário começar considerando a questão: no Brasil, a quem interessaria uma literatura húngara traduzida? Ou, em outras palavras, quem seria o público alvo desta literatura? Ou ainda, qual seria o interesse em introduzir no sistema literário brasileiro a literatura produzida na Hungria, já que, segundo John Milton "uma tradução não é analisada isoladamente, simplesmente em conexão com seu original, mas é vista como parte de uma rede de relações que inclui todos os aspectos da língua-alvo". [MILTON, 1998, p. 184] A introdução de tal literatura no Brasil teria relevância a ponto de promover as inovações discutidas por Milton? Parece que a melhor abordagem para esta questão é verificar "o desenvolvimento histórico

\footnotetext{
1 Doutora em Estudos da Tradução, USP. Todas as traduções do húngaro e do inglês são de minha autoria.

2 CANDIDO, A. Formação da Literatura Brasileira - Momentos Decisivos. Rio de Janeiro: Ouro sobre Azul, 2007.

3 MILTON, J. Tradução - Teoria e Prática. São Paulo, Martins Fontes, 1998. Capítulo VII "A tradução como força literária” p 183-204.
} 
da tradução em uma dada sociedade" [1998, p. 188] - no caso, a ocorrência de tradução de literatura húngara no sistema literário brasileiro -, para verificar sua abrangência e influência.

Portanto, a segunda questão, quase que decorrência natural da primeira, é: existe tal literatura traduzida? Qual sua configuração? Quais os agentes envolvidos no processo? Isto é, quem traduziu e o que foi traduzido? Seriam os tradutores eles mesmos escritores brasileiros renomados, uma das modalidades sugeridas por Even-Zohar ${ }^{4}$ ao analisar a posição da literatura traduzida dentro de um polissistema literário? Se não, quem seriam os tradutores e com que motivação teriam produzido suas traduções? Essa questão será relevante durante a avaliação da função da literatura traduzida já que, ainda segundo Even-Zohar, as relações do texto original dentro de seu sistema literário original não serão as mesmas do texto traduzido quando incorporado ao sistema alvo: "É claro que os princípios que definem a seleção das obras a serem traduzidas são determinadas pelas circunstâncias que regem o polissistema original" [EVEN-ZOHAR, 1990, p. 46 e 47]. Considerando as diferenças culturais existentes entre sistemas literários tão distantes quanto o brasileiro e o húngaro, a presente reflexão irá procurar desvendar as circunstâncias do polissistema original e ver de que forma elas podem ser responsáveis pela recepção do público brasileiro.

Além disso, é interessante verificar também se o volume de literatura húngara traduzida teria força para exercer alguma influência na literatura brasileira, já que outro ponto relevante discutido por Antonio Candido refere-se à formação de uma continuidade literária. A idéia é verificar se as obras húngaras traduzidas, ao integrarem o sistema brasileiro, teriam "influenciado a elaboração de outras que as sucederam, estabelecendo deste modo uma tradição contínua de estilos, temas, formas". [CANDIDO, 2007. p. 26/27]. Como se verá mais adiante, na verdade a literatura húngara traduzida no Brasil representa, segundo os termos de Antonio Candido, muito mais uma manifestação literária, cuja principal característica é a ausência de uma continuidade histórica ininterrupta, ou a ausência de uma tradição. [2007. p. 25] Pelo menos numa fase inicial.

Andre Lefevere", ao refletir sobre "a função da tradução numa cultura", primeiro examina como uma tradução funciona em um contexto mais amplo de

4 EVEN-ZOHAR, I. “The Position of Translated Literature within the Literary Polysystem”, IN: Poetics Today 11:1 (1990), pp. 45-51.

5 LEFEVERE, A. Translating Literature - Practice and Theory in a Comparative Literature Context. New York: Modern Language Association of America, 1992, p. 114. 
uma literatura e, por extensão, em uma cultura, já que a tradução, em geral, preenche um vácuo. Para ele, a tradução também implica na existência de uma autoridade que delega a tarefa da tradução a ser feita. Ou, voltando a Even-Zohar [1990, p. 46], na existência da autoridade que a seleciona.

\section{Características da língua húngara x prováveis tradutores}

Assim, para que a primeira hipótese de Even-Zohar fosse aplicável, teríamos que ter escritores brasileiros, renomados ou não, que conhecessem a língua húngara a ponto de poder traduzir a literatura daquele país. Porém, pode-se adivinhar de antemão, que essa condição nunca existiu por conta das características da língua magiar e o nível de conhecimento necessário para que se possa dela traduzir. Nos conta Guimarães Rosa no famoso ensaio Pequena Palavra ${ }^{6}$ que a língua húngara

pertence ao ramo ugriano-finês da grande família turaniana, tanto quanto o finlandês e o turco: mas seus mais parentes, mesmo assim não muito próximos, com esses formando porém o magiar um subgrupo linguístico, são os idiomas falados por pequenos grupos de nômades da rena ou pescadores, na Sibéria: o ostiaco e o vogul. [1998, p. 23] ${ }^{7}$

[...] O que eles buscam, às inspirações, toda-a-vida, é a máxima expressividade [...] São todos individualistas. Desde que o entenda, cada um pode e deseja criar sua 'língua' própria, seu vocabulário e sintaxe, seu ser escrito. Mais do que isso: cada escritor húngaro, na prática, quase que não pode deixar de ter essa língua própria, pessoal. O alcance disso é mágico. [p. 29]

E, na sequência, Guimarães Rosa cita um jornalista húngaro famoso, ${ }^{8}$

Cada jornal, em Budapeste, é escrito em seu dialeto "da casa", às vezes fora da linguagem culta corrente, diz Laczkó Géza; e ajunta: "Na vida da

6 ROSA, J.G. Pequena Palavra. IN: Antologia do Conto Húngaro, de Paulo Rónai. Rio de Janeiro: Topbooks, 1998, $4^{\text {a }}$ ed. p. $13-32$.

7 Guimarães Rosa também fala da língua escrita pelos "felizes escritores húngaros” que dispõem de um "aparelho de tanta liberdade". [p. 28]

8 Jornalista, escritor, tradutor literário e professor, Laczkó Géza (1884-1953) pertenceu à primeira geração da revista Nyugat, e participou não somente de seu lançamento como também foi um de seus colaboradores assíduos. 
sociedade húngara não basta ter-se espírito; mas a forma lingüística do dito espirituoso tem também de ser espirituosa". [idem]

Ou Paulo Rónai, que, ao introduzir sua obra, usa um tom de voz semelhante ao de Guimarães Rosa. Diz Rónai: "estabelecido na região mais central e fértil da Europa [...], no lugar de embate de continentes, religiões e impérios, esse povo oferece à literatura o solo fecundo de uma alma trágica". Convivendo com vizinhos que pertencem a três grandes blocos lingüísticos, isto é, o eslavo, o latino e o germânico, "o magiar mantém-se estranho e desirmanado, numa independência que constitui enigma para os estudiosos". [RÓNAI, 1998, p. 35]. Essas características determinam também o isolamento de sua literatura:

Extremamente rico de possibilidades de expressão, mais manejável do que outra qualquer língua civilizada (pois cada bom escritor o recria constantemente), esse idioma por isso mesmo rodeia os que dele se servem de uma barreira quase intransponível.

Traduções feitas diretamente do húngaro, a não ser para o alemão (língua da vizinha Áustria, à qual a Hungria durante séculos esteve ligada por laços antes constitucionais que afetivos), contam-se pelos dedos; em português não conheço nenhuma, salvo as que eu mesmo executei: as demais são versões, às vezes em terceiro ou quarto grau. [RÓNAI, 1998, p. 35 e 36] ${ }^{9}$

Ou seja, a língua húngara não somente é singular, totalmente distante das línguas ocidentais, como também tem peculiaridades em seu expressar literário, e esses fatores sugerem que traduzi-la é uma operação restrita a poucos. Diante disso, e confirmado pelo inventário da literatura húngara traduzida no Brasil, vê-se que não é pertinente considerar a primeira hipótese de Even-Zohar, no caso, que escritores brasileiros de renome que conhecessem a língua original elegeriam traduzir aquela literatura para português. Mesmo traduções indiretas, como se verá, foram poucas e bem específicas.

A literatura húngara é singular não somente para os brasileiros, mas como ressaltou Paulo Rónai, muito pouco dela foi traduzida a nível global, pelo menos até o último quarto do século XX. Assim, para que o leitor brasileiro tenha acesso à literatura húngara, em geral, o tradutor tem que: a) ou ser húngaro nativo, que

9 RÓNAI, P. Antologia do Conto Húngaro. Rio de Janeiro: Topbooks, 1998, $4^{\mathrm{a}}$ ed. A primeira edição foi publicada em 1957, portanto Rónai refere-se às traduções produzidas até então. 
por força de circunstâncias de vida - restrições econômicas, políticas e sociais -, deixou sua terra natal e emigrou para o Brasil, onde aprendeu o português como segunda língua e então produziu traduções; b) ou ser descendente de húngaros, que não mais tem a língua como nativa, mas a domina o suficiente e/ou se aperfeiçoou nela a ponto de ser capaz de produzir traduções. Ou, como no caso de Paulo Rónai, ter aprendido português ainda na Hungria, antes de emigrar para o Brasil e já ser tradutor profissional em seu país de origem, mas, salvo engano, ele foi caso isolado. A segunda hipótese é, portanto, a que ocorre de fato.

Nunca é demais ressaltar que as considerações desta análise se referem, grosso modo, aos primeiros dois terços do século XX. A partir da queda do muro de Berlim, do conseqüente declínio da antiga URSS e independência húngara do domínio soviético, da entrada da Hungria na União Européia, com a globalização e o advento da internet e as inovações ocorridas no campo da tecnologia e comunicação, para citar alguns fatos mais próximos ao tema em estudo, as condições de vida se alteraram tanto que muitas conclusões desse estudo já não poderiam ser consideradas válidas para o momento atual.

\section{A trajetória da análise}

A partir daqui será examinada, com mais profundidade, a segunda questão levantada, isto é, quem no Brasil seria o público alvo de uma literatura húngara traduzida. Como já se viu, devido ao seu isolamento, até recentemente, essa literatura não havia criado fama a ponto de entrar para o cânone universal, portanto não era conhecida nem pela intelectualidade internacional muito menos pela brasileira. Destarte, ela também não poderia despertar o interesse de um provável público leitor brasileiro, a não ser que passasse a ser conhecida por agentes que fossem familiarizados tanto com aquela literatura como com este público alvo. Também será verificado se surgiram condições históricas para que uma tradição, nos termos definidos por Antonio Candido, pudesse ser estabelecida, em todos os aspectos apontados - continuidade e influências de estilos, temas, formas - ou somente parte. Para isso, será verificado quem seriam os prováveis protagonistas que pudessem levar a cabo a consecução dessa provável tradição.

\section{Tradutores de literatura húngara no Brasil}

Num primeiro momento, quase que em doses homeopáticas, o agente que cumpriu esta tarefa pioneira de trazer a literatura húngara para o Brasil, não só 
selecionando o que seria adequado como também traduzindo, foi o crítico literário e tradutor Paulo Rónai, que chegou ao Brasil em 1941, aos 34 anos de idade, já dominando a nossa língua, que ele aprendera sozinho em Budapeste cerca de três anos antes. Portanto, intelectual com uma carreira já consolidada na Hungria, ao chegar ao Brasil, ele faz esse trabalho pioneiro de divulgar a literatura húngara através de palestras - no dia 22 de julho de 1941 deu sua primeira palestra sobre literatura húngara na Academia Brasileira de Letras, em português - e também de publicação de traduções e artigos de crítica literária em jornais e posteriormente em livros. ${ }^{10}$

Além de conquistar reconhecimento geral como crítico literário humanista, no Brasil Rónai se tornou uma referência na colônia húngara já que a maioria das pessoas que tinha algum interesse em publicar traduções do húngaro, passou a buscar seu apoio de diversas formas. ${ }^{11}$ Um exemplo é Noel Delamare - pseudônimo literário de Roberto Lyra $\mathrm{F}^{\circ}$, que apesar de professor na área jurídica, por mais de trinta anos também se dedicou ao estudo e à tradução de poesia, publicando sob o pseudônimo de Noel Delamare em jornais e revistas - que, tendo ciência dos efeitos do isolamento literário acima citado, concebeu um projeto que batizou de Cancioneiro dos Sete Mares "com o fim de apresentar em português a lírica estrangeira que, por algum motivo permanecesse desconhecido aqui no Brasil, ou aqui tivesse uma divulgação inadequada". ${ }^{12}$ Ele, então, decidiu dedicar o primeiro

10 Para informações sobre a obra e a vida de Paulo Rónai, consultar SPIRY, Z. Paulo Rónai, um brasileiro made in Hungary. Disponível online http://www.teses.usp. br/teses/disponiveis/8/8147/tde-18112009154021/pt-br.php Além disso, consultar RÓNAI, P. Como Aprendi Português e outras Aventuras. São Paulo: Globo, 1992.

11 Um caso, que de outra forma não poderia vir a público, já que a informação se localiza no acervo de correspondência particular de Paulo Rónai, é o de Áron Gábor, jornalista e intelectual húngaro que foi deportado para a Sibéria em 1944. Quinze anos depois, ao retornar, publicou sua história em húngaro, num gênero conhecido como literatura de testemunho. Traduzido para várias línguas, quis publicar também aqui no Brasil. Segundo correspondência entre o autor e Paulo Rónai, este o apoiou na revisão da tradução brasileira elaborada nos anos 1970 a partir da tradução inglesa, que Rónai também comparou com o original húngaro e deu parecer a respeito. Rónai também intermediou os trâmites da publicação no Brasil junto à editora e introduzir "notas de editor" no texto brasileiro esclarecendo topônimos russos e terminologia específica dos campos de trabalhos forçados. Contudo, não se encontra nenhuma referência ao nome de Paulo Rónai nos dois volumes publicados em português. Ver GÁBOR, Áron: (1) Ao Leste do Homem. Rio de Janeiro, Cia Editora Americana, 1972. (2) Liberdade Quadrada. Rio de Janeiro: Pallas S/A, 1976. Os fatos só ficam conhecidos quando se consulta a correspondência entre autor e editor, no acervo de Rónai, toda ela em húngaro.

12 DELAmAre, N. O Cancioneiro dos Sete Mares. In: “A Tradução da Grande Obra Literária”, Tradução \& Comunicação, vol. 2. São Paulo, Ed. Álamo, 1982, p. 80-101. 
volume de seu projeto à poesia do poeta húngaro Endre Ady. ${ }^{13}$ Conta Delamare que primeiro recorreu a Paulo Rónai que lhe forneceu "traduções literais e prosaicas" da poesia de Ady. A partir disso, ele as cotejou com versões em língua que dominava [espanhol, francês, inglês, alemão, italiano ou russo], até produzir sua própria versão poética para o português brasileiro. Na correspondência entre eles - confinada no acervo particular de Rónai - existe uma intensa troca de informações sobre questões semânticas relativas à poesia de Ady, a questões culturais, e assim por diante.

Também Nelson Ascher, nascido no Brasil mas filho de imigrantes húngaros, recebeu orientação e críticas construtivas de Paulo Rónai, a quem conheceu pessoalmente, no início de sua jornada como tradutor de poesia húngara para português. Com o tempo, além de jornalista e poeta, Ascher se especializou em crítica literária, tendo publicado suas traduções poéticas húngaras em jornais e revistas. Por exemplo, em Dicta \& Contradicta de junho de 2009, ${ }^{14}$ com o título Poesia híngara moderna, ele publicou uma antologia bilíngüe, com treze poetas húngaros, devidamente contextualizada com uma apresentação sucinta, mas abrangente, da história política e literária da Hungria. 19 anos antes, além de trazer a público suas traduções poéticas húngaras em jornais desde o início dos anos 1990, Ascher já havia publicado poesia húngara traduzida por ele, no livro Canção da Ceifa, prefaciado por Rónai. No posfácio deste livro, o tradutor-poeta conta sobre seu início e de como Rónai lhe serviu de mestre na arte de traduzir poesia húngara:

Em 1973 eu tinha 15 anos e Petöfi 150. Ou melhor: a Hungria [...] comemorava os 150 anos do nascimento de seu poeta nacional [...] Sándor Petöfi, nascido em 1823 e desaparecido em batalha em 1849, quando sua pátria perdia para os russos a guerra de independência que começara a mover no ano anterior com os Habsburgos. Um almanaque húngaro que meus avós recebiam anualmente reproduzia na capa um retrato impressionante do poeta e apresentando alguns de seus poemas mais famosos, entre eles a Canção Nacional, um dos estopins da guerra em questão.

Foi o primeiro poema que li numa língua que, de certa forma, julgava restrita aos meus familiares e a alguns de seus amigos. Nessa mesma época eu descobria, através de Camões e Pessoa, a poesia de língua portuguesa, mas

13 Delamare, N. Canção do Jacobino Húngaro - Endre Ady. Vol. I - Canção dos Sete Mares. 1979. [edição do autor].

14 ASCHER, N. Poesia Húngara Moderna. São Paulo: Dicta \& Contradicta, publicação semestral do Instituto de Formação e Educação. Junho de 2009, nº 3, p. 158-173 
a tríade romântica húngara - Vörösmarthy e Arany, além do próprio Petöfi - estava, embora mais distante da minha compreensão idiomática imediata, mais próxima do meu mood. Sabendo da existência da poesia na língua dos meus ancestrais e de sua possibilidade na minha, meti-me a traduzir, sem preparo prévio ou indagações teóricas, a tríade húngara para o português, começando pela Canção Nacional. Remeti a Paulo Rónai, cujo endereço um amigo da família me havia dado, os primeiros resultados dessa investida inicial. Ele foi, para dizer o mínimo, generoso ${ }^{15}$. Pouco depois comecei a tomar maior contato com a literatura magiar através de sua magnífica $A n$ tologia do Conto Húngaro, uma revelação, e com a arte da tradução através de seus deliciosos Escola de Tradutores e $A$ Traducão Vivida. Um outro livro de Rónai, Como Aprendi o Português e Outras Aventuras, despertou meu interesse em Endre Ady, o revolucionário fundador da poesia moderna em seu país, e Miklós Radnóti, que, assassinado em 1944 pelos nazistas húngaros devido ao crime de ser judeu, tornou-se, com Garcia Lorca e Óssip Mandelstam, um dos três maiores poetas vítimas da barbárie totalitária do presente século. ${ }^{16}$

Ao ler Ascher, revela-se uma outra característica da poesia húngara, muito típica: a liderança da luta social não é desempenhada pela classe política, mas pela intelectualidade ${ }^{17}$. É com a leitura em público de seu poema mais famoso, que o poeta Petöfi Sándor incita a população a dar seu grito pela liberdade, no dia que viria a ser considerado como o dia nacional da Independência na Hungria.

15 Consultar também Entrevista com Nelson Ascher, volume 11 deste Cadernos de Literatura em Tradução. [ver nota 34 adiante].

16 ASCHER, N. Canção antes da ceifa (tradução de poesia húngara moderna, com prefácio de Paulo Rónai). São Paulo: Arte Paulo Brasil, 1990.

17 Ascher não é o único a destacar tal característica. Em entrevista especial para a Carta Maior - http:// agenciacartamaior.uol.com.br/ - um intelectual húngaro de renome internacional, que atualmente vive na Inglaterra, István Mészáros, assim descreve essa ambiente: "Fui criado em Budapeste, onde o desenvolvimento cultural - especialmente no que se refere às relações estreitas entre a literatura criativa e o pensamento social e político - era muito especial, talvez único. Isso porque os maiores e mais radicais poetas da nossa literatura nacional, como Sándor Petőfi, Endre Ady e Attila József, eram também os mais profundos e abrangentes pensadores húngaros de sua época. Nos seus apaixonados escritos líricos tanto quanto em suas reflexões teóricas, eles trataram dos mais desafiadores temas da sociedade na sua perspectiva histórica, oferecendo soluções revolucionárias, elevadas e abrangentemente perspicazes, capazes de resistir ao teste do tempo.” Por isso Paulo Rónai dizia que esses poetas inflamavam opiniões. 


\section{Imagem 1}

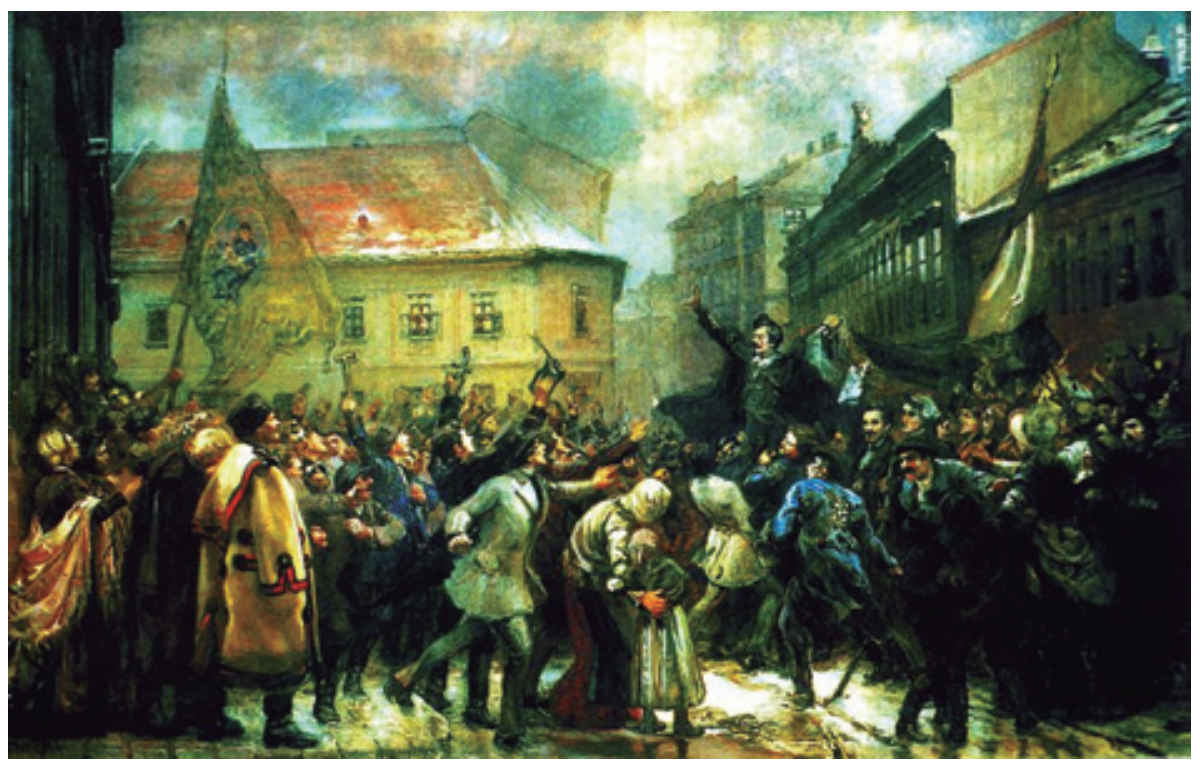

Por János Thorma - Talpra magyar - representa Petöfi Sándor declamando a Canção Nacional em 15 de março de 1848.

$\mathrm{Na}$ interação entre Ascher e Rónai, e na influência exercida por Rónai sobre o jovem poeta-tradutor, observam-se indícios de continuidade, o que sugere o estabelecimento da tradição definida por Antonio Candido. Quando lê as traduções que Ascher publicou, da poesia do húngaro Radnóti na Folha de São Paulo, Rónai lhe escreve em carta: "Estou feliz por já ter um sucessor que torne conhecida a literatura húngara no Brasil. Estas suas traduções são especialmente tocantes para mim, pois Radnóti Miklós foi um amigo querido, com cuja viúva mantenho contato até hoje." [Carta de Rónai para Ascher, datada de 5 de agosto de 1984, em húngaro, localizada no acervo particular de Paulo Rónai, Nova Friburgo, RJ.] No campo da crítica literária sem dúvida isto se tornou realidade. Mas na poética, apesar de ter sido um prolífico tradutor de poesia na Hungria, tendo iniciado sua carreira traduzindo, por exemplo, clássicos latinos para húngaro, no Brasil Rónai não se dedicou a esta atividade [ver Spiry 2009], sendo portanto Ascher pioneiro na tradução de poesia húngara para português brasileiro.

Também classificados na segunda categoria de tradutores, isto é, descendentes de húngaros, existem dois tradutores bastante ativos atualmente na categoria 
prosa. Ildikó Sütő, apesar de nascida em Budapeste, deixou o país quando tinha cinco anos de idade, e depois de uma temporada de quatro anos na Áustria, aqui chegou em 1949. Cresceu e trabalhou no Brasil como secretária trilíngue - inglês, alemão e português - e, depois de aposentada, em 1991 decidiu se dedicar a traduzir a literatura da língua que sempre usou no seio da família e entre os amigos da colônia húngara. A história do psicanalista Paulo Schiller ${ }^{18}$ começa com publicação autoral em sua área de especialização e traduções para inglês. Quando seu editor adquiriu os direitos autorais do húngaro Sándor Márai - O Legado de Eszter-, Schiller já era da casa, digamos assim, e o convite para ele traduzir seu primeiro romance húngaro foi um passo. Além de Márai e Imre Kertész [Nobel de Literatura de 2002] traduziu também autores húngaros modernos como Dragomán e Eszterházy. Vale a pena também mencionar o experiente Alexandar Jovanovic, ${ }^{19}$ professor de Linguística na Escola de Educação da USP, pois é um caso de bilinguismo: filho de mãe húngara e pai sérvio, residentes na região que hoje se chama Voivodina - originalmente Szabadka, em húngaro, região que foi incorporada à extinta Iugoslávia depois de 1918, mas que atualmente pertence à Sérvia - aprendeu e praticou as duas línguas, húngaro e servo-croata, dentro de casa desde a infância, já que ambos pais falavam os dois idiomas. Em seu invejável currículo inúmeras traduções não somente do húngaro [ver nota 35 a seguir] mas de vários outros idiomas da região.

Em comum entre esses tradutores, a língua húngara passou para segundo plano na maior parte de suas atividades profissionais no Brasil, e seu convívio com ela foi, de início, muito mais relacionado à comunicação com familiares, para mais tarde servir como ferramenta para a prática do ato tradutório.

\section{As diversas ondas migratórias húngaras que chegaram ao Brasil}

Retomando então a questão inicial, a quem interessaria no Brasil ler literatura húngara traduzida? Já vimos que o público leitor brasileiro, pelo menos na fase inicial, não tinha acesso a tal literatura, e também não tinha interesse, por

\footnotetext{
18 Ver artigo de Paulo Schiller: Reflexões sobre o bilinguismo, e participação em Psicanálise e Literatura - Imre Kertész e o Desterro Humano, ambos nesta revista

19 Ver artigo de Alexandar Jovanovic Cinco poetas da Europa Centro-Oriental: forja mágica de metáforas e temas, nesta revista. Para as publicações de Jovanovic não somente traduções de húngaro mas das várias línguas que domina, ver Currículo Lattes em: https://uspdigital.usp. br/tycho/CurriculoLattesMostrar?codpub =E7A0B594D82E\#Artigospublicados
} 
desconhecê-la. Seriam então os imigrantes húngaros os prováveis interessados em ler uma literatura húngara traduzida? Como veremos a seguir, estes também não se caracterizaram como seu público alvo, por uma razão simples: eles liam no original. Seriam então seus descendentes de segunda ou terceira geração? Ou esta literatura atenderia outros interesses, talvez áreas específicas do saber como a literatura de testemunho exemplificada na nota de pé de página no 11 acima?

Para poder avançar mais nessas questões, vamos rapidamente caracterizar como se deu a presença húngara em solo brasileiro e a partir de quando. Para uma visão mais abrangente, apresenta-se primeiro a diáspora húngara global, para depois detalhar as levas de imigrantes que chegaram especificamente ao Brasil. As estatísticas apontam para seis ondas migratórias principais, ${ }^{20}$ várias devido às perseguições políticas e outras motivadas por questões econômicas.

\begin{tabular}{|c|c|l|}
\hline $\begin{array}{c}\text { Onda } \\
\text { migratória }\end{array}$ & $\begin{array}{c}\text { data e/ou } \\
\text { período }\end{array}$ & \multicolumn{1}{c|}{ motivação } \\
\hline $1^{\text {a }}$ & 1849 e 1867 & $\begin{array}{l}\text { Perseguições políticas advindas da frustrada insurreição de } \\
1848, \text { contra a dominação da Casa dos Habsburgos. }\end{array}$ \\
\hline $2^{\text {a }}$ & $\begin{array}{c}1867-1920 \\
\text { (tratado de } \\
\text { Trianon) }\end{array}$ & $\begin{array}{l}\text { Questões econômicas: difíceis condições de vida devido ao } \\
\text { Compromisso de 1867 que promoveu a saída em massa } \\
\text { de agricultores, importante êxodo da região nordeste da } \\
\text { Hungria (entre 1920 e 1924). }\end{array}$ \\
\hline $3^{\text {a }}$ & $\begin{array}{c}1920-\text { II } \\
\text { Guerra Mundial }\end{array}$ & $\begin{array}{l}\text { Razões políticas, filosóficas e existenciais provocaram um } \\
\text { exodo de dentro dos grupos intelectuais burgueses e artistas. }\end{array}$ \\
\hline $4^{\text {a }}$ & $\begin{array}{c}\text { II Guerra } \\
\text { Mundial }\end{array}$ & $\begin{array}{l}\text { Motivação política - perseguição nazista e instauração do } \\
\text { regime socialista da URSS -, e também escassez de recursos } \\
\text { econômicos. }\end{array}$ \\
\hline $5^{\text {a }}$ & $\begin{array}{c}\text { Revolução de } \\
\text { outubro 1956 }\end{array}$ & $\begin{array}{l}\text { Repressão política e cerceamento da liberdade. Instauração do } \\
\text { regime da comunista. Grande empobrecimento da população. }\end{array}$ \\
\hline $6^{\text {a }}$ & $\begin{array}{l}\text { Pós queda } \\
\text { URSS }\end{array}$ & $\begin{array}{l}\text { Hungria entra para a UE o que permite acesso a melhores } \\
\text { oportunidades de emprego na Inglaterra e na Alemanha. }\end{array}$ \\
\hline
\end{tabular}

A segunda e a sexta onda migratória foram fortemente motivadas por questões econômicas como conseqüência de decisões políticas anteriores. Se as primeiras ondas levaram muitos húngaros a terras distantes como a Nova Zelândia

20 Consultado online 05/01/2016 - minha tradução do húngaro. http://www.balassiintezet.hu/attachments/article/1036/Magyar Emigracios es Diaszpora Kozpont.pdf 
e a Austrália - algumas fontes citam a febre do ouro da era vitoriana -, Estados Unidos e Canadá também foram destinos muito procurados devido às oportunidades de trabalho que ali existiam, e principalmente, sempre presente a idéia de "quanto mais longe da Europa, melhor" ${ }^{21}$ [VERO, p. 37]. A América Latina foi um destino eleito por um número significativo de emigrantes.

$\mathrm{Na}$ virada do XIX para o XX, entre a $2^{\mathrm{a}}$ e $3^{\mathrm{a}}$ onda principalmente, segundo algumas fontes, existiam até agências de recrutamento de mão de obra nas aldeias das regiões desmembradas da Hungria por força do Tratado de Trianon. Na época o Brasil vivia as conseqüências da escassez de mão de obra nas fazendas devido à abolição da escravatura, e principalmente o Estado de São Paulo que experimentava a época de ouro do ciclo do café. Um sonho comum entre os agricultores húngaros emigrantes era fazer fortuna em terras longínquas e retornar para a sua terra natal em condições financeiras melhores. Mas os constantes conflitos na Europa da época começaram a dar a entender que o sonhado retorno à pátria teria que ser adiado. Os húngaros, depois do flagelo que o país sofreu como conseqüência do Tratado de Trianon quando perdeu $2 / 3$ de seu território e $1 / 2$ de sua população, mal se libertaram dos nazistas no final da II Guerra Mundial logo foram dominados pelas forças soviéticas que impuseram seu regime totalitário no país. $\mathrm{Na}$ verdade, quase ninguém dentre a $1^{\mathrm{a}}$ geração de imigrantes húngaros fez o tão sonhado caminho de volta.

Estima-se que, no total, cerca de 5 milhões de húngaros tenham emigrado do país, tanto da Hungria como dos territórios desmembrados, notadamente da Checoslováquia, Romênia e Iugoslávia [vide mapa 1]. Desse total, 30\% se estabeleceu nos EUA e 6\% no Canadá. Outros destinos principais: Israel, Alemanha, França, Reino Unido e Austrália. Na América Latina, além do Brasil, segundo as estatísticas, receberam um número expressivo de imigrantes húngaros: Argentina, Venezuela e Chile.

21 VERO J. Alma Estrangeira - Pequenas Histórias de Húngaros no Brasil- Processos Identitários. São Paulo: Ágora, 2003. 


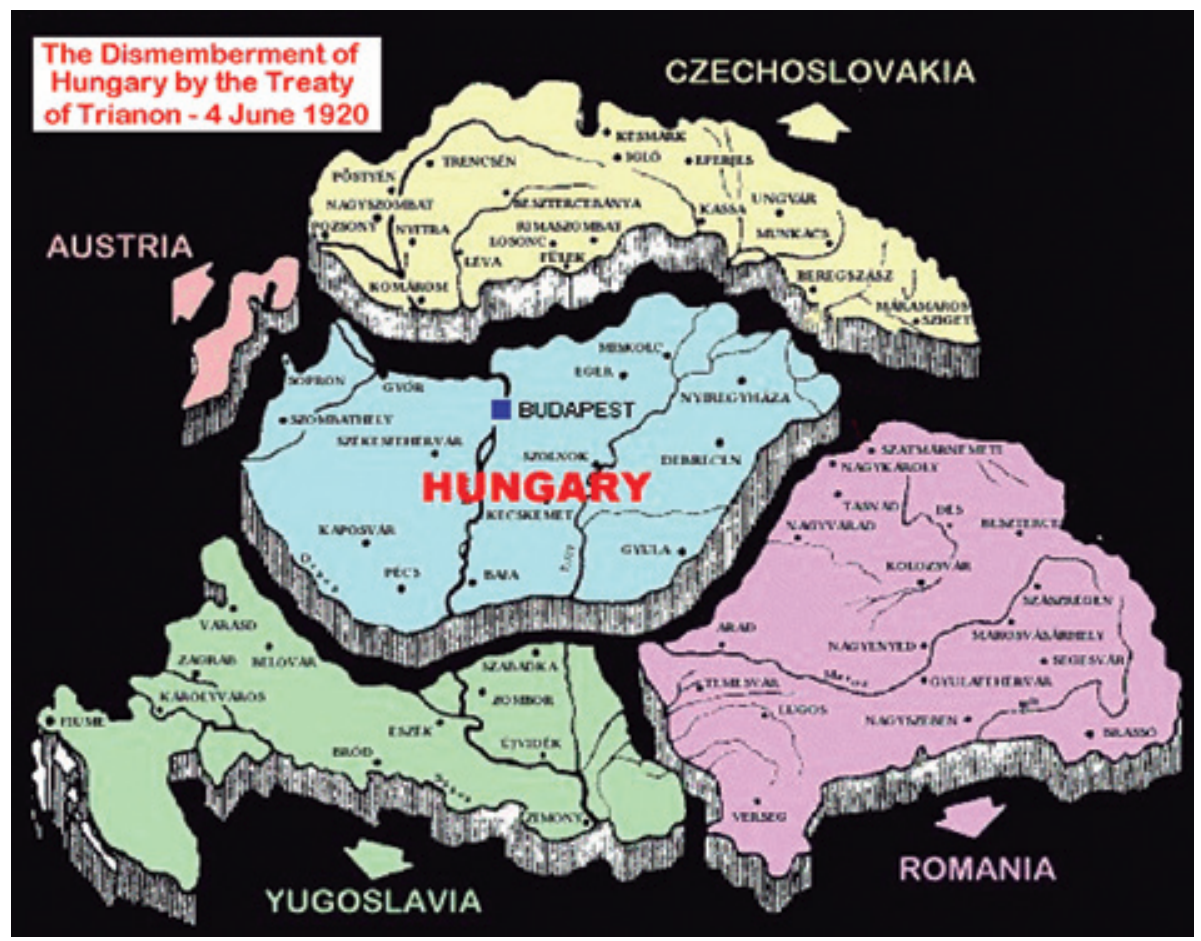

Mapa 1 - O Reino da Hungria desmembrada como conseqüência do tratado de Trianon.

\section{Características sócio-culturais dos imigrantes húngaros}

Um ponto interessante, para este estudo, é a força congregadora que a religião exerceu na organização das colônias húngaras. Ainda na virada do XIX para o XX, os húngaros nos EUA, por exemplo, começaram a formar suas colônias e a construir suas igrejas, fundar suas escolas e jornais, estabelecer organizações de assistência, e assim por diante. Não somente lá. Também no Brasil as colônias se organizaram em função de suas crenças religiosas. Quando se estabeleciam em alguma colônia, os imigrantes construíam suas casas próximo à sua igreja (os húngaros são principalmente católicos ou protestantes, mas um contingente razoável de judeus húngaros também elegeu o Brasil como segunda pátria) e à sua escola. Relevante observar que essas escolas comunitárias alfabetizavam também na língua húngara. Além disso, formavam organizações de cunho social para apoio comunitário, grupos de teatro e de dança folclórica e, principalmente, lançavam jornais escritos em sua língua nativa, distribuídos por toda colônia. No Brasil, por 
exemplo, 1922 marca o ano de lançamento do jornal húngaro Délamerikai Magyar Hírlap (Jornal Húngaro da América Latina), inicialmente semanal, mas a partir de outubro de 1925 editado a cada dois dias. Em sua edição de 15/06/1933, por exemplo, informa que, na época, estimava-se que 150.000 seria o número de imigrantes húngaros residindo no Brasil, dos quais 30.000 em São Paulo [a fonte ${ }^{22}$ não deixa claro se São Paulo seria o Estado ou a Capital]. Desse total, cerca de 90\% se referia a trabalhadores na agricultura e que não falava a língua local. Segundo o mesmo jornal, edição de 21/09/1926, um grande contingente de imigrantes húngaros tinha chegado à cidade de São Paulo vindo das fazendas do interior do Estado, onde o clima e as condições de trabalho não lhes permitiam sobrevivência condizente. Várias fontes consultadas citam esse êxodo do campo para a cidade, destacando que, então, os agricultores viraram operários de fábrica. ${ }^{23}$

Uma questão de interesse para o propósito desta análise é lembrar que, apesar de haverem deixado sua terra natal premidos por condições políticas e/ou econômicas, na verdade "o cidadão húngaro tinha arraigado o desejo de permanecer fiel às suas raízes magiares, à sua língua e cultura" [ver nota 23]. Foi nesse ambiente social que surgiu a necessidade de se criar uma organização de assistência, constituída formalmente em 18/09/1926: Brazíliai Magyar Segélyegylet, isto é, Associação Beneficente Húngara do Brasil, atualmente denominada Associação Beneficente 30 de Setembro. Esta Associação existe e é ativa até hoje, na cidade de São Paulo. Um grande problema social que a Associação teve que enfrentar foi a dificuldade de se provar que muitos imigrantes que vieram com passaportes da Romênia, ou da Iugoslávia, enfim, dos territórios desmembrados do Reino da Hungria (nome oficial do país antes do Tratado de Trianon) eram na verdade, húngaros de fato. Nos registros oficiais brasileiros eles possuíam passaporte romeno (30.437), tcheco (518), iugoslavo (16.518) e austríaco (2.742). Apesar de constarem somente 6.501 portadores de passaporte húngaro, o total de imigrantes húngaros do período do levantamento era, na verdade, de 56.716 famílias. $^{24}$

22 Emlékekönyv: 1926 a 1996. Fennállásának hetvenedik évfordulójára - Magyarország 1100-ike évében. Anuário da Associação Beneficente 30 de Setembro em celebração ao $70^{\circ}$ aniversário de sua constituição - 1926 a 1996 - no $1100^{\circ}$ ano da nação Húngara. São Paulo: São Paulo Ind. Gráfica Ltda., 1996. Publicado em húngaro.

23 ZOLCSÁK, I. Imigração Húngara. IN: História da Imigração no Brasil - As famílias. São Paulo: Serviço Nacional de Divulgação Cultural Brasileiro, 1983, p. 129.

$24 \mathrm{Na}$ época era comum somente o chefe da família ter passaporte e o restante da família figurar no passaporte do pai. Por isso, muitos registros não falam de pessoas mas sim de famílias. 


\section{Escolas primárias que ensinam húngaro no Brasil}

Uma função de destaque da Associação Beneficente foi a manutenção de escolas húngaras de ensino primário. Entre 1927, quando se inaugurou a primeira dessas escolas em São Paulo, e 1951, quando a última escola encerrou suas atividades, a Associação participou da criação e manutenção de sete escolas na capital, nos bairros de Vila Anastácio, Moóca, Vila Pompéia, Ipiranga, Pirituba, Vila Ipojuca, Freguesia do Ó, Vila Maria e Santo André, assim como as cinco escolas das colônias agrícolas localizadas no sudoeste do Estado de São Paulo, na região da alta sorocabana - entre os atuais municípios de Presidente Wenceslau e Presidente Epitácio. Uma maneira que encontraram para contornar a imposição durante o período de exceção foi re-nomeando as escolas e contratando também professores brasileiros.

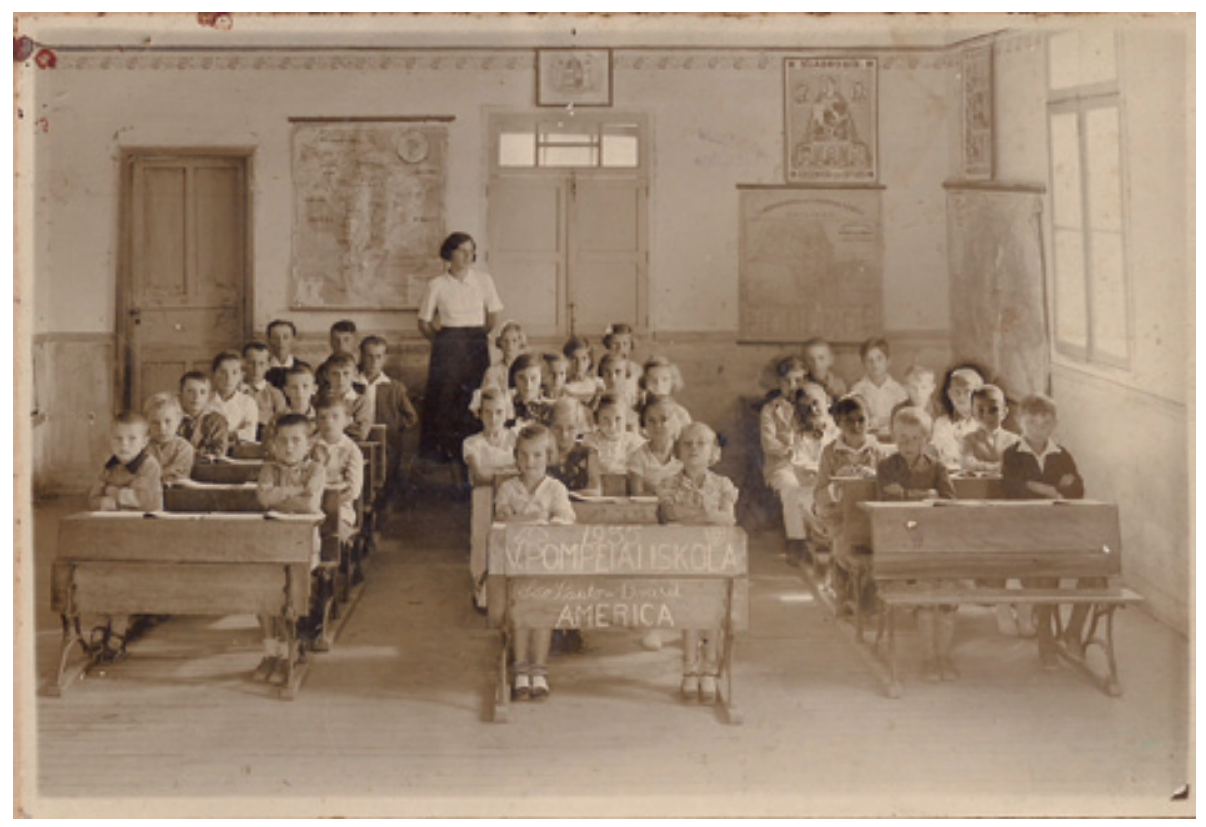

Figura 1 - Escola mixta (sic) húngara-brasileira da Vila Pompéia, 1935. 


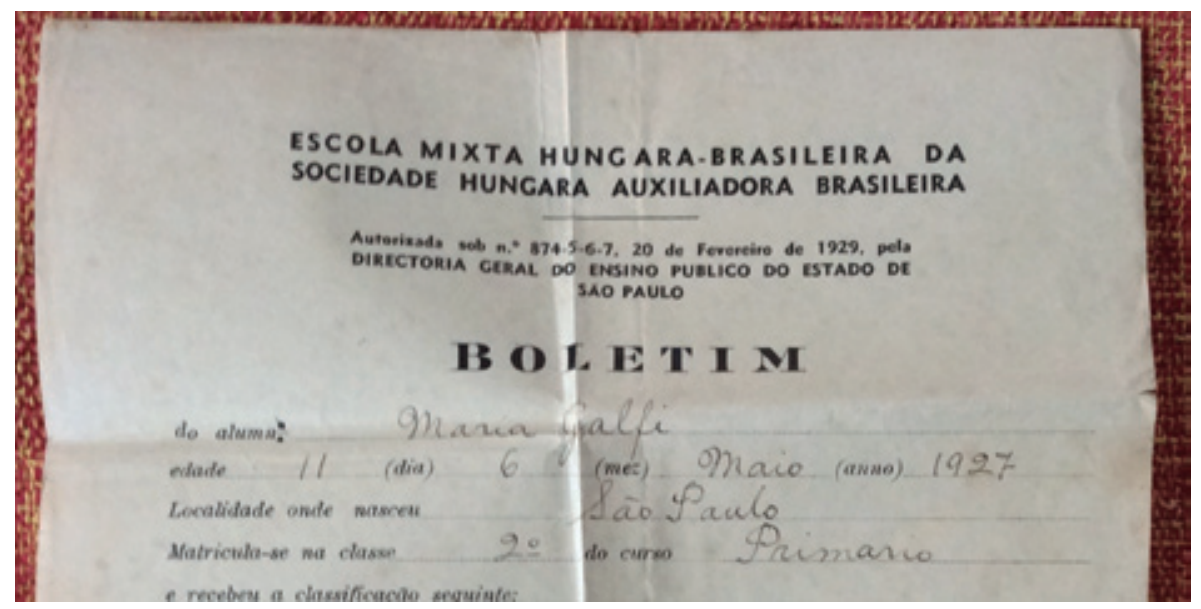

Figura 2 - Detalhe boletim 1938.

Diferente dessas escolas primárias, que mantinham vivas as tradições húngaras e também alfabetizavam as crianças na língua de sua antiga pátria, o Colégio Santo Américo - fundado em São Paulo por padres beneditinos húngaros - sempre manteve o currículo brasileiro, apesar de apoiar a colônia de muitas outras maneiras. Vale ressaltar que com o movimento de Nacionalização promovido durante a II Guerra Mundial pelo governo de Getúlio Vargas, houve muita repressão ao ensino e ao uso das línguas estrangeiras em solo nacional. Principalmente nas colônias agrícolas, onde as pessoas anteriormente não sentiam necessidade de aprender o português, a proibição de uso de suas línguas maternas provocou enormes problemas sociais, pois havia gente que, mesmo morando no Brasil, nunca na vida soube falar outra língua que não a de sua antiga origem, como alemão ou húngaro, e assim por diante. ${ }^{25}$

\section{A colônia húngara na cidade de São Paulo}

Contrastando com a realidade dos imigrantes agricultores, os imigrantes húngaros analisados por Judith Vero [ver nota 21] eram "profissionais liberais, comerciantes e técnicos e pertenciam à classe média da Europa Central, com

25 LOPES, S.M. Nós Somos Húngaros! O Reavivamento das tradições húngaras em Jaraguá do Sul-SC. Dissertação de Mestrado. UNIVILLE, 2011. p. 114. Consultado online 08/01/2106. http://univille.edu.br/community $/$ mestradopcs $/$ VirtualDisk.html?action=downloadFile\&file=Sidnei.PDF\&current=/Dissertacoes. 
valores desse caldo cultural. [...] Trouxeram consigo algum dinheiro e objetos de casa, falam mais de uma língua e já viajaram antes" de emigrar para o Brasil. A maioria dos que eram judeus "deixaram a religião para trás: por praticidade, desinteresse, vergonha, conveniência, mas sobretudo por medo, muito medo. Muitos enfrentaram perseguições e até prisões." [2003, p. 27] Ao longo de seu estudo, Vero constata que apesar de aprenderem a língua com relativa rapidez, e de obterem certo sucesso financeiro em um tempo razoavelmente curto, também esse grupo de imigrantes se isola dentro de seu próprio ciclo de amizades. Em geral, devido ao forte sistema educacional da Hungria da época em foco, o imigrante magiar educado traz em sua bagagem uma cultura geral diferenciada, e essa condição lhe permite galgar a posições de liderança nas atividades econômicas, ou criar negócios próprios que irão ajudar a impulsionar a incipiente indústria brasileira.

A publicação já mencionada - História da Imigração no Brasil, As Famílias - traz o relato de várias famílias húngaras que transformaram seus pequenos negócios familiares em indústrias. ${ }^{26}$ Uma dessas histórias começa na região desmembrada que atualmente pertence à Romênia. Emeric Laky, que trabalhava no setor técnico de instalações telefônicas para o governo da Hungria antes do Tratado de Trianon, em 1924 veio se refugiar no Brasil. Em sua bagagem traz livros técnicos que lhe permitiriam dar continuidade à sua profissão na área de telefonia [ver Fig. 3]. Seu filho Wilhelm Laky se transformou em um pequeno industrial metalúrgico especializado no ramo de armarinhos, criador dos colchetes marca Predilecta, atividade que requeria que toda família ajudasse na montagem das cartelas. [ver Fig. $4]^{27}$ Para que seus filhos pudessem estudar, a família Laky trouxe, em sua exígua bagagem, livros húngaros sobre Geografia e livros de contos e lendas de sua terra natal. [ver Fig. 5 e 6]

26 História da Imigração no Brasil - As famílias. São Paulo: Serviço Nacional de Divulgação Cultural Brasileiro, 1983, p. 250.

27 Idem, p. 191. 


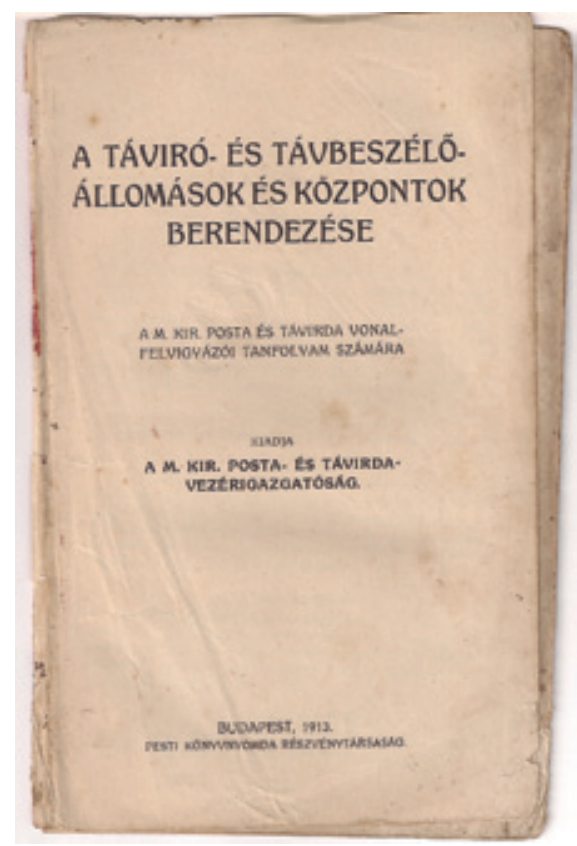

Figura 3 - Capa do livro húngaro sobre instalações de linhas telefônicas e telegráficas, de 1913.

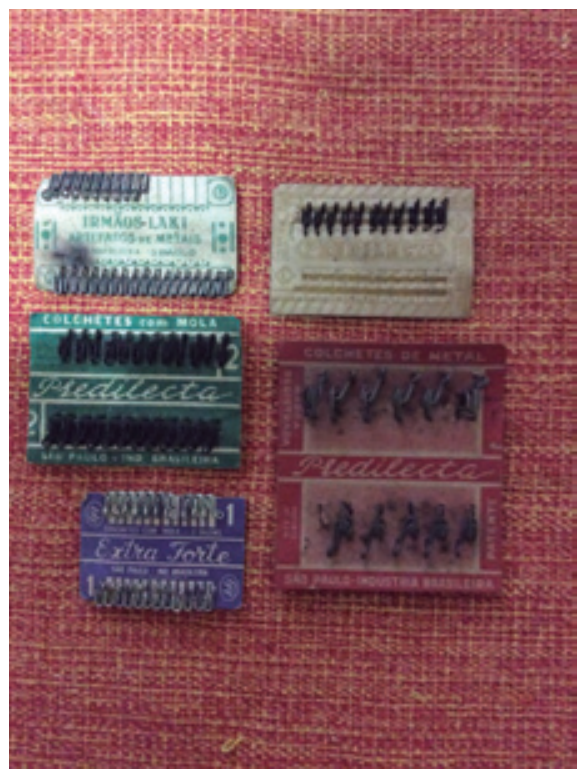

Figura 4 - Cartelas de colchetes marca Predilecta. 


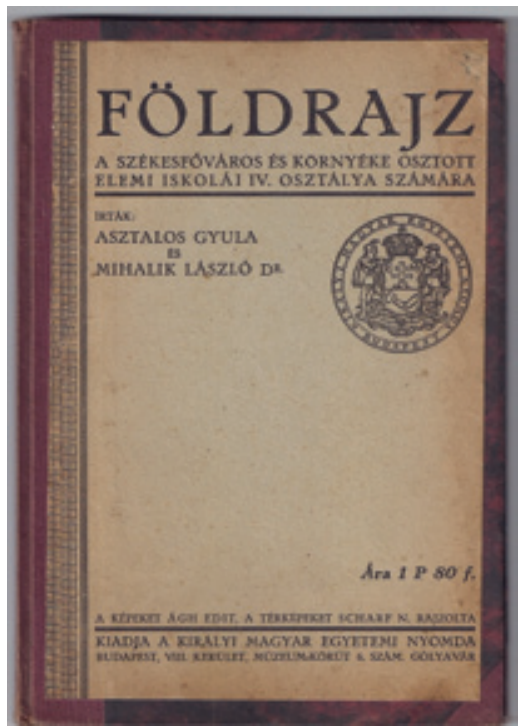

Figura 5 - Capa de livro de geografia, publicado na Hungria.

as

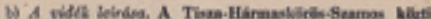

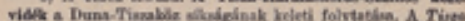

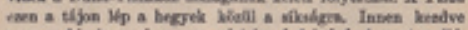

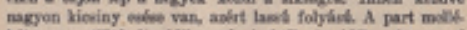

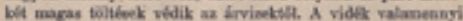

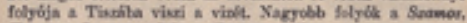

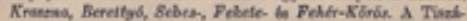

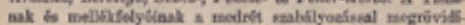

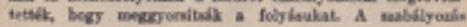

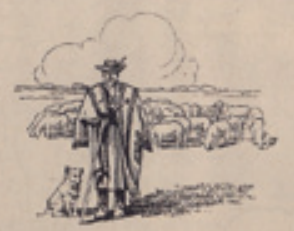

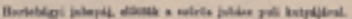

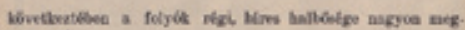
easpant.

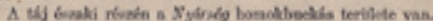

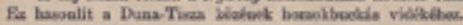

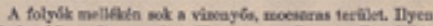

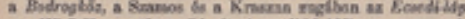

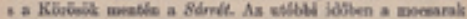

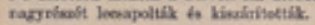

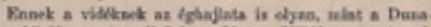

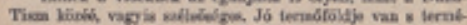

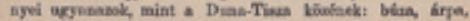

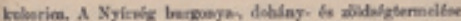
cresiges jeientínégî.

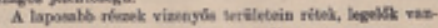

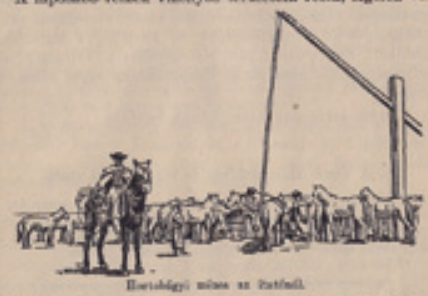

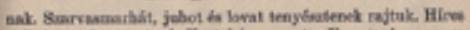

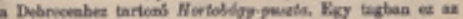

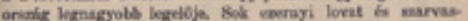
marthis hectiontent ist.

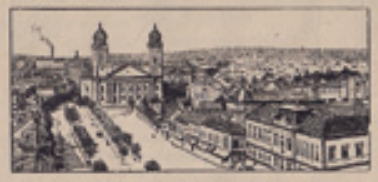

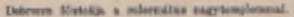

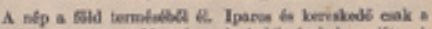

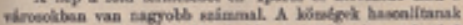

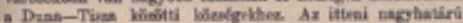

Figura 6 - página interna livro de Geografia. 
Lajos Boglár, cônsul da Hungria em São Paulo por 14 anos (de 1927 a 1942), fazia visitas constantes às diferentes localidades onde a colônia húngara estava espalhada e anotava suas impressões. Ele escreve:

Depois da missa, pelas manhãs de domingo, como na Hungria, lá estavam os sérios trabalhadores e operários em seus ternos pretos. Trocávamos algumas palavras, apertos de mão, uma pergunta, uma resposta. Não havia necessidade de muita conversa, nós nos conhecemos bem.

[...] Homens com seus bigodes caídos, um e outro com casaco húngaro, todos com a dignidade do camponês. ERAM (sic) tipos estranhos estes camponeses. Nos dias comuns, trabalhavam no porão do frigorífico por um mísero salário diário de poucos mil-réis, mas aos domingos, na praça da igreja de Anastácio, tinham porte de príncipes.

Era gostoso conversar com estes aristocratas da terra. Mas o que lhes interessava de fato? Podia-se conversar com eles sobre a safra, reclamar dos impostos, ou, durante a seca, augurar chuva. Porém, era a política, a situação da pátria deles que lhes interessava mais. [...] Ao falarmos da história da Hungria e da política externa magiar, podíamos conhecer verdadeiramente o quanto havia de bom senso no camponês húngaro, fruto bem mais de sua sagacidade do que da sua escolaridade. ${ }^{28}$ [Grifos meus]

A ausência de escolaridade que Boglár destaca não significa alienação. O camponês húngaro que o cônsul encontra na missa de domingo e que, portanto já é operário de fábrica, ${ }^{29}$ mantém sua dignidade e seu interesse pelas coisas da pátria distante, a ponto de merecer o respeito do representante do governo húngaro. Um sentimento patriótico e nacionalista próprio do cidadão húngaro, destacado por muitos autores que discutem a questão húngara, como por exemplo, John Lukács, ${ }^{30}$ William O. McCagg ${ }^{31}$ ou ainda Raphael Patai que abre o capítulo dedicado ao tema dizendo que: "Os historiadores da literatura húngara costumavam

28 BOGLÁR, L. Mundo húngaro no Brasil: do século passado até 1942. Tradução de Magda Boglár Baló. São Paulo: Humanitas/FFLCH/USP, 2000, p. 174.

29 Anastácio é um bairro industrial de São Paulo, hoje conhecido como Vila Anastácio.

30 LUKÁCS, J. Budapest 1900 - Um retrato histórico de uma cidade e sua cultura. Rio de Janeiro: José Olympio Ed., 2009. Várias referências, consultar índice remissivo "nacionalismo".

31 McCAGG, W.O. Jewish Nobles and Geniuses in Modern Hungary. Colorado: Boulder, 1973. 
argumentar, com orgulho especial, que a literatura húngara é um registro do patriotismo húngaro". ${ }^{32}$ [grifo meu]

O objetivo desse destaque é a determinação do perfil cultural do imigrante húngaro e também, a especificidade temática de literatura magiar, para compreender a proximidade ou a distância desta com os interesses literários do leitor brasileiro. Desse modo, conclui-se que a grande massa de imigrantes húngaros, definitivamente, não era um público idealmente consumidor de literatura húngara traduzida para português: ou porque não sabiam o idioma local, ou porque tinham como objetivo manter os laços culturais com a pátria de origem e preferiam ler seus textos naquela língua. Diferentemente de seus descendentes, essa $1^{a}$ geração de imigrantes, grosso modo, não se aculturou, não se miscigenou em sua nova pátria. ${ }^{33}$

\section{As gerações de descendentes}

Já a $2^{\mathrm{a}}$ geração, que nasceu no Brasil ou que aqui chegou ainda na infância, buscou naturalmente se integrar à sociedade brasileira. Devido ao convívio com familiares não aculturados por um lado, e as demais situações de vida a que são expostos, os membros da $2^{a}$ geração tem uma experiência cultural mista, passando a confrontar as diferenças culturais. Em sua pesquisa para determinar os processos identitários entre os imigrantes húngaros, Judith Vero entrevista muitas pessoas tanto da primeira como da $2^{\mathrm{a}}$ geração, à qual ela mesma pertence já que nasceu na Hungria e chegou ao Brasil aos 6 anos de idade. Diferente de Nelson Ascher que associa sua iniciação na cultura brasileira com suas leituras de Monteiro Lobato e ao MPB, ${ }^{34}$ Vero se declara totalmente identificada com a cultura brasileira por ter sido alfabetizada em português [VERO, 2003, p. 23]. A comunicação com os familiares era toda em húngaro assim como os hábitos alimentares que seguiam os costumes originais. Quanto à religiosidade, a frase "Havíamos sido judeus, éramos agora católicos" pode parecer uma afirmação estranha para um brasileiro que nunca tenha experimentado nenhum tipo de perseguição em sua vida, mas

32 PATAI, R. The Jews of Hungary - History, Culture, Psychology. Detroit: Wayne State Univ. Press, 1996, page 269.

33 Ver Judith Vero, nota 21 acima.

34 Entrevista com Nelson Ascher, na edição de no 11 deste Cadernos de Literatura em Tradução, p. 318. Disponível online http://www.revistas.usp. br/clt/article/view/49503. Consultado em dezembro/2015. 
não para as pessoas que haviam escapado do nazismo. O relato de Vero pode ser endossado pela maioria dos jovens da $2^{a}$ geração de imigrantes húngaros:

Crescemos sob a égide da duplicidade. Minha família achava que as crianças deviam estudar idiomas e piano. Nossos colegas e vizinhos, naquela época (1950), brincavam depois do horário escolar. Ninguém tinha tantas aulas particulares como nós. Enquanto os amigos andavam de bicicleta, patinavam, jogavam bola, nós estudávamos. Nossos amigos recebiam, como presentes de aniversário e Natal, brinquedos. Nós, livros, roupas e sapatos. $\mathrm{Na}$ escola nossos lanches eram ignorados enquanto os dos colegas eram cobiçados. Nossos sanduiches de pimentão provocavam risos à nossa volta.

No começo da adolescência fizemos a primeira comunhão com todo o grupo da escola. Mas nossos pais não deram ao evento maior importância. Não houve festa e nem almoço familiar como na casa de nossos amigos. Aliás, no quesito festas de família ficávamos sempre a desejar. Éramos poucos, pois a maioria havia ficado para trás, na Hungria. Portanto, nossos fins de semana eram diferentes. Não tínhamos avós, nem macarronada aos domingos. [VERO, 2003, p. 24]

As diferenças culturais apontadas por esses dois parágrafos, mais as anotações e comentários de Boglár acima citadas, e o patriotismo húngaro exacerbado citado por Patai e outros, dão uma amostra da distância entre os hábitos culturais brasileiros e húngaros. Isto aliado à descrição que Nelson Ascher deu de suas primeiras aventuras no campo da tradução poética, quando descobriu a Canção Nacional de Petöfi Sándor, nos leva a concluir que a literatura húngara não fez eco no Brasil, durante um determinado período, devido à distância que separa os interesses temáticos dessas duas culturas, um dos pontos destacados por Antonio Candido como determinante da criação de uma tradição literária. Por mais bela que seja a Canção Nacional para um húngaro imbuído desse espírito patriótico, cujas palavras Talpra magyar, hí a haz̧a ["Levante-se ó povo húngaro, a nação lhe chama"] lhe fazem ferver o sangue nas veias, para o brasileiro médio, que nunca vivenciou uma guerra, não tem nenhuma repercussão. Talvez, por oportuno, valha a pena recorrer a um outro texto do próprio Nelson Ascher, em que ele aponta para o verdadeiro sentido da literatura criada naquele canto do mundo. Este trecho faz parte do prefácio com que Ascher apresenta a primeira obra publicada pela "Coleção LESTE”, cujo objetivo era exatamente trazer para o leitor brasileiro um "filão riquíssimo de imaginação 
contemporânea", antes indisponível para ele. A conclusão de Ascher também aponta para o estranhamento desnudado por Vero. Nos conta Ascher:

Até o final da Primeira Grande Guerra, a maior parte da Europa Centro-Oriental pertencia a dois impérios, o russo e o austro-húngaro. Ambas as construções políticas eram tão intrincadas, tão carregadas de contradições e contra-sensos, que não chega a causar espanto o fato de tantos autores modernos dessa região terem se dedicado a uma literatura do absurdo ou do grotesco. Essa tendência, celebrizada, por exemplo, pelo cidadão de Praga Franz Kafka ou pelo romeno Ionesco, reforçou-se ainda mais na medida em que as mudanças históricas subsequentes patentearam que, nessa "outra" Europa, todos os tipos de desvario eram mesmo autóctones.

Assim, o que nas duas novelas do húngaro István Örkény pode parecer mais estranho para o público brasileiro é justamente o que seus leitores originais reconhecem como familiar. [grifo meu] ${ }^{35}$

Mais uma vez se conclui que a temática da literatura húngara, carregada de conteúdo político, é exógeno ao leitor brasileiro. Sempre lembrando que talvez depois da globalização, que trouxe em seu bojo complexas questões de mobilidade social e suas consequências, que redesenhou as fronteiras pelo menos dos países que foram palco de todas as questões apontadas, estas considerações tenham que ser revistas.

\section{A $3^{\text {a }}$ geração, ou os descendentes húngaros atuais}

A geração atual, que grosso modo está sendo chamada de $3^{a}$ geração, já não sente "saudade" de sua pátria original, já está totalmente assimilada à cultura brasileira. Mesmo assim, por exemplo, ao visitar a residência da família Laky pela primeira vez, recentemente, próximo da celebração do Natal, pude novamente sentir aquela familiaridade que havia percebido ao visitar Judith Vero em 2008, devido a traços culturais mutuamente presentes em nossas vidas [eu também nasci em Budapeste e vim para o Brasil aos 7 anos de idade]: toalhinhas de crochê, ou bordadas, espalhadas pelos móveis da sala, almofadas bordadas com motivos húngaros no sofá ou nas poltronas, da cozinha vem um cheiro de

35 ASCHER, N. Prefácio. In: A Exposição das Rosas, de István Örkény, tradução do original húngaro de Aleksandar Jovanovic. Rio de Janeiro: Ed. 34, 1993. (Coleção LESTE). P. 7. 
biscoitos caseiros sendo assados para as Festas que se avizinhavam, tudo isso convida reminiscências tão familiares. Uma espécie de reconhecimento através de marcas culturais que ainda estão presentes entre os membros da $3^{\text {a }}$ geração, às vezes manifestas através de objetos de decoração, ou no cardápio familiar, ou ainda por traços distintivos de caráter.

Agora, a partir do último quarto do século XX e início do XXI, com as novas perspectivas que o mundo globalizado permite, em que as barreiras impostas pelas antigas questões políticas foram eliminadas, essa $3^{\text {a }}$ geração dos descendentes húngaros começa a voltar seu olhar para a pátria natal de seus antecedentes. A grande maioria desta geração já não sabe mais húngaro e está começando a reaprender a língua, mas tem muita curiosidade sobre suas raízes. Em virtude do novo panorama político mundial, das facilidades oferecidas pelo governo atual da Hungria no sentido de reconhecer os descendentes como cidadãos húngaros vivendo no exterior, ${ }^{36}$ e pela elevação de poder aquisitivo dessa geração e a própria facilidade com que se pode viajar para o exterior atualmente, que lhes permite talvez percorrer o tão sonhado "caminho de volta" de seus ancestrais, considerando as reflexões aqui elaboradas, talvez possamos concluir que essa $3^{a}$ geração se configure como um provável público alvo para consumir literatura húngara traduzida no Brasil.

\section{A nova realidade através de novas temáticas e de fama literária}

A nova configuração do mundo globalizado também fez surgir outras temáticas modernas, com o caso da literatura de testemunho de Imre Kertész, que ainda desfruta da vantagem da fama literária, impulsionado pelo Prêmio Nobel de Literatura com que foi laureado em 2002. Esta literatura conquista novas áreas de interesse no Brasil, notadamente a psicologia ${ }^{37}$ e um novo público alvo, desvinculado dos descendentes húngaros.

Um autor húngaro que entrou no sistema literário brasileiro recentemente, via tradução, é Sándor Márai. Além de passar pela porta da fama editorial - por

36 Ver, por exemplo, boletim da Associação Húngara 30 de Setembro, relatório bilíngue sobre o Programa Kőrösi Csoma Sándor - página 6 do boletim disponível online consultado em janeiro/2016. http://www. ahungara.org.br/hirado/hirado 73/hirado73.pdf?utm source=akna\&utm medium=email\&utm camp aign $=$ Boletim $+\mathrm{H} \% \mathrm{CDRAD} \% \mathrm{D} 3+$ deste + trimestre $\% 2 \mathrm{C}+\mathrm{j} \% \mathrm{E} 1+\mathrm{est}^{2} \% \mathrm{E} 1+$ no + ar $\% 21$

37 O tema foi objeto de um evento no Instituto de Psicologia da USP, cujas palestras estão transcritas em artigo deste Cadernos de Literatura em Tradução: Psicanálise e Literatura - Imre Kertész e o Desterro Humano. 
conta do sucesso que seus livros desfrutavam na Itália, seus direitos autorais foram adquiridos por editores brasileiros -, em uma de suas obras Márai aborda um tema brasileiro: O Veredicto de Canudos. O sucesso desta publicação comprova o que foi discutido anteriormente sobre a influência que a proximidade ou distanciamento cultural da temática da obra literária tem sobre sua recepção na cultura de chegada.

A abertura política pela qual a Hungria passou depois que se libertou do domínio soviético, e concomitante entrada na União Européia, possibilitou que sua literatura experimentasse uma maior abertura fora do país. Novos autores vão conquistando fama em várias ambientes literários pelo mundo, e esse sucesso acaba chegando ao Brasil também. Por exemplo, György Dragomán e Péter Eszterházy, ambos traduzidos por Paulo Schiller para a Cosac Naify.

Para encerrar, deve-se relembrar que a única obra húngara publicada no Brasil que entrou para o nosso cânone - aliás não somente o nosso, mas do mundo inteiro, confirmando o que declarou um editor: "um livro vende bem quando é bom" -, que já passou de uma centena de reedições só no mercado brasileiro, é Os Meninos da Rua Paulo, de Ferenc Molnár, traduzido por Paulo Rónai em 1952. Mas, uma manifestação literária única não configura uma tradição, não tem força para influenciar "uma tradição contínua de estilos, temas e formas" [CANDIDO, 2007 , p. 26/27]. Uma realidade que a configuração do atual mundo globalizado, como se viu, pode alterar completamente.

\section{Conclusão}

A literatura húngara passa a fecundar o sistema literário brasileiro somente a partir dos autores modernos, com a literatura de testemunho, um campo específico do saber. Os autores clássicos da literatura húngara chegaram ao Brasil somente através de contos. Três dos tradutores citados, Paulo Rónai, Ildikó Sütö e Paulo Schiller, publicaram Antologias de Contos. Nelson Ascher, cuja especialização é o gênero poesia, lançou uma antologia poética já citada, Canção da Ceifa, além da publicação em Dicta \& Contradicta comentado acima, e volta e meia publica traduções em diversos meios modernos.

Com relação à capacitação dos tradutores, observa-se que à exceção de Nelson Ascher que é profissional, os demais tradutores se "profissionalizaram" mas não são tradutores profissionais. Exercem sua atividade principal e também, paralelamente, a tradução. 
Segundo os critérios adotados para esta reflexão, à exceção da literatura de testemunho, dentro do sistema literário brasileiro a literatura húngara traduzida caracteriza somente uma manifestação literária. 